\title{
POLÍTICAS PÚBLICAS DE EDUCAÇÃO NO BRASIL: FRACASSO ESCOLAR, CULPABILIZAÇÃO DOS ALUNOS E INOCENTIZAÇÃO DA ESCOLA
}

\author{
POLÍTICAS PÚBLICAS DE EDUCACIÓN EN BRASIL: FRACASO ESCOLAR, \\ CULPABILIZACIÓN DE LOS ALUMNOS E INOCENTIZACIÓN DE LA \\ ESCUELA JANINE
}

\section{PUBLIC POLICIES OF EDUCATION IN BRAZIL: SCHOOL FAILURE, BLAME OF THE STUDENTS AND INNOCENCE OF THE SCHOOL JANINE}

\author{
Janine Marta Coelho RODRIGUES ${ }^{1}$ \\ Wilson Honorato ARAGÃO ${ }^{2}$ \\ Silvestre Coelho RODRIGUES ${ }^{3}$
}

RESUMO: O presente estudo discute as políticas da educação no Brasil, voltadas às questões da culpabilização da criança que fracassa na escola, a partir da unilateralidade do olhar, quando a escola se recusa a discutir seus critérios de avaliação, seleção e classificação. Desconsiderar os contextos sociais, familiares e econômicos dos alunos, significa considerar que estes alunos apresentam desempenhos iguais, adquirem as suas competências e habilidades a partir do mesmo método pedagógico e com o mesmo ritmo de aprendizagem. Este estudo evidencia a falsidade dessas premissas, quando reconhece a relevância das diferenças individuais e a tentativa de inocentização da escola em relação ao seu próprio desempenho. Recentes pesquisas (2015) apontam que as dificuldades de aprendizagem resultam no fracasso escolar, representam despreparo dos professores para entender as diferenças, erros pedagógicos na adoção de métodos que se distanciam dos repertórios linguísticos e culturais das crianças. Percebe-se, também, a ausência de uma mediação por parte de Trabalhador Social entre a família, a escola e a comunidade para oportunizar o sucesso da criança na escola.

PALAVRAS-CHAVE: Educação. Escola. Fracasso escolar. Avaliação. Contextos.

RESUMEN: El presente estudio discute las políticas de la educación en Brasil, dirigidas a las cuestiones de la culpabilización del niño que fracasa en la escuela, a partir de la unilateralidad de la mirada, cuando la escuela se niega a discutir sus criterios de evaluación, selección y clasificación. En el caso de los alumnos, los alumnos tienen un desempeño igual, adquieren sus competencias y habilidades a partir

\footnotetext{
1 Universidade Federal da Paraíba (UFPB), João Pessoa - PB - Brasil. Professora Titular Classe E. Doutora em Educação. E-mail: jmcoelho@ig.com.br.

${ }^{2}$ Universidade Federal da Paraíba (UFPB), João Pessoa - PB - Brasil. Professor Associado II. Doutor em Educação. E-mail: wilsonaragao@hotmail.com.

${ }^{3}$ Universidade Federal da Paraíba (UFPB), João Pessoa - PB - Brasil. Professor Assistente -Dedicação Exclusiva. Professor colaborador do projeto de extensão atendimento a criança hospitalizadaHULW/UFPB. Participa do Grupo de Pesquisa sobre Formação Docente. E-mail: silvestrecrodrigues@gmail.com.
} 
del mismo método pedagógico y con el mismo ritmo de aprendizaje. Este estudio evidencia la falsedad de esas premisas, cuando reconoce la relevancia de las diferencias individuales y el intento de inocencia de la escuela en relación a su propio desempeño. Las recientes investigaciones (2015) apuntan que las dificultades de aprendizaje resultan en el fracaso escolar, representan despreparación de los profesores para entender las diferencias, errores pedagógicos en la adopción de métodos que se distancian de los repertorios lingüísticos y culturales de los niños. Se percibe también la ausencia de una mediación por parte del Trabajador Social entre la familia, la escuela y la comunidad para oportunizar el éxito del niño en la escuela.

PALABRAS CLAVE: Educación. Escuela. Fracaso escolar. Evaluación. Contextos.

ABSTRACT: The present study discusses education policies in Brazil, focused on issues of blame of the child who fails in school, from the unilaterality of the gaze, when the school refuses to discuss its evaluation, selection and classification criteria. Disregarding the social, family and economic contexts of the students means to consider that these students have equal performances, acquire their skills and abilities from the same pedagogical method and with the same pace of learning. This study evidences the falsity of these premises, when it recognizes the relevance of the individual differences and the attempt of the school's innocence in relation to its own performance. Recent research (2015) points out that learning difficulties result in failure at school, represent teachers' unpreparedness to understand differences, and pedagogical errors in adopting methods that distanced themselves from children's linguistic and cultural repertoires. It is also noticed the absence of Social Worker mediation between the family, the school and the community to facilitate the success of the child in school.

KEYWORDS: Education. School. School failure. Evaluation. Contexts.

\section{Algumas considerações inicias}

A perversidade em adotar uma postura equivocada de culpabilização da criança por seus fracassos, faz com que essa idéia extrapole os muros locais e globais das instituições educacionais, quando analisa as transformações das teorias, dos projetos pedagógicos e psicopedagógicos que pretensamente poderiam ser desenvolvidos frente a compreensão do papel da escola, dos professores e das famílias.

Com um novo sentimento educativo, os profissionais ligados aos atendimentos especializados de prevenção e estimulação, se propõem a construir um olhar integral sobre a multidimensionalidade e complexidade do ser humano, que tem alguma dificuldade em aprender ou apresenta deficiência ou descompassos em seu desenvolvimento.

Organizando apontamentos sobre cultura, saúde e educação pensamos que a Educação entre suas várias finalidades, deve se permitir formar profissionais 
capacitados para desenvolver atividades que atendam não só de necessidades psicopedagógicas mas também que sejam capazes de planejar e executar atividades voltadas ao aconselhamento familiar, conhecendo e identificando os problemas encontrados nos processos de aprendizagem nos contextos familiares das crianças.

Discutir com professores, familiares e demais interessados, os argumentos mais aceitos como políticas públicas, para que os processos constitucionais compartilhados e garantidos nos desafios cotidianos da convivência social sejam processos efetivos de inclusão social, favorecendo a continuidade das ações aqui consideradas foco dos fenômenos estudados: direitos construídos e constitucionalmente garantidos, instituindo as questões da responsabilização social, nos levam à experiências enriquecedoras de construções pessoais e sociais, onde se aborda e se reflete sobre as possibilidades de uma cidadania plena, numa sociedade justa e igualitária.

A educação infantil é o marco inicial das aprendizagens, desse modo ao freqüentar uma instituição de educação infantil, as crianças desenvolvem sua convivência social, seu desenvolvimento cognitivo, psicomotor, afetivo e social, através do compartilhamento das atividades compatíveis à sua idade, construindo também, suas identidades como pessoas, como cidadãs.

Torna-se difícil então compreender, por que segundo dados oficiais, 8 milhões de crianças menores de três anos estão fora das creches no Brasil. A meta atual do governo ainda está longe de ser cumprida. O governo queria construir seis mil creches até o fim de 2014. Até agora, 1.180 foram entregues e o déficit de vagas chama a atenção. Segundo dados do Ministério da Educação, o país tem quase dez milhões e meio de crianças entre zero e três anos. Só dois milhões e meio foram matriculadas no ano de 2013 , menos de $25 \%$.

Da Declaração Universal dos Direitos Humanos, de 10 de dezembro de 1948, os seus desdobramentos nos documentos que se seguiram, surgiram a Declaração Universal dos Direitos da Criança e do Adolescente (1959), a Constituição da República Federativa do Brasil (1988), a Convenção Internacional dos Direitos da Criança e do Adolescente (1989) e outros que corporificaram no Brasil, o Estatuto da Criança e do Adolescente.

A Constituição Federal garante, em seu artigo 205, que "a educação, direito de todos e dever do Estado e da família, será promovida e incentivada com a colaboração da sociedade, visando ao pleno desenvolvimento da pessoa, seu preparo para o exercício da cidadania e sua qualificação para o trabalho". 
A Lei de Diretrizes e Bases da Educação Nacional, LDB/96, determina que o ensino infantil é de responsabilidade dos municípios, embora o Governo Federal repasse recursos às prefeituras municipais, os municípios, segundo a Confederação Nacional dos Municípios, alegam que a verba repassada é insuficiente para manter creches em funcionamento. O Plano Plurianual varia de município para município, pela especificidade e territorialidade de suas demandas, apesar da Constituição Federal ter determinado o processo de descentralização político-administrativa e municipalização.

Desde que foi sancionada a Lei Federal 8.069, de 13 de julho de 1990, conhecida como Estatuto da Criança e do Adolescente, os direitos e deveres da criança e do (a) adolescente, as responsabilidades do Estado, da sociedade e da família, com o futuro das novas gerações, os princípios de direito, além de transformar essa parcela da população brasileira como prioridade, destina recursos para que políticas e programas sociais sejam executados no sentido do acolhimento, desenvolvimento e oferecimento de oportunidades para as crianças, os(as) adolescentes e suas famílias.

O Estatuto da Criança e do Adolescente veio a construir uma rede de espaços sociais, para que, em sistema de colaboração, de efetivação de parcerias publicas, privadas e do terceiro setor, respeite, atenda e desenvolva ações capazes de promover e garantir os direitos fundamentais de crianças e adolescentes nos municípios brasileiros. E enfatiza o atendimento em relação às políticas prioritárias de saúde e educação, aos direitos constitucionais de vida, saúde, alimentação educação, cultura, proteção especial, adotadas no país como meio eficaz de reduzir o abandono das crianças, minimizar as desigualdades sociais e diminuir a evasão e repetência escolar.

Direito à Educação, à Cultura, ao Esporte e ao Lazer, observando o desenvolvimento pessoal e social da criança e do(a) adolescente, tem na portaria 1.656, de 28 de novembro de 1994, a premissa de que: "toda educação, por definição, deve ser preventiva para o exercício da cidadania e para a melhoria da qualidade de vida, bem como recomenda a inclusão da prática da educação preventiva integral nos conteúdos e atividades curriculares da educação infantil, fundamental e ensino médio". Esses marcos legais, em geral, apontam para as violações mais frequentes à este direito.

No Art. 53. Do ECA, a criança e o adolescente têm direito à educação, visando ao pleno desenvolvimento de sua pessoa, preparo para o exercício da cidadania e qualificação para o trabalho, assegurando-lhes:

I-igualdade de condições para o acesso e permanência na escola;

II-direito de ser respeitado por seus educadores; 
III-direito de contestar critérios avaliativos, podendo recorrer às instâncias escolares superiores;

IV-direito de organização e participação em entidades estudantis;

$\mathrm{V}$-acesso à escola pública e gratuita próxima de sua residência.

Parágrafo único. É direito dos pais ou responsáveis ter ciência do processo pedagógico, bem como participar da definição das propostas educacionais.

Alguns documentos institucionais, frutos de lutas e movimentos sociais, expressam um olhar cuidadoso e preocupado com o desenvolvimento integral desses brasileiros, na perspectiva de dar condições concretas e ações organizadas que viabilizem programas e políticas para que saiam do papel e aconteçam.

A Lei de Diretrizes e Bases da Educação Nacional (1996) ressalta que a Educação abrange processos formativos mais amplos que se desenvolvem na vida familiar e na convivência humana junto à sociedade como um todo, em sua dinâmica histórica e cultural.

Em uma sociedade marcada pela desigualdade social, com um grande número de jovens e adultos(as) analfabetos(as), com políticas educacionais restritivas em relação ao acesso às vagas nas escolas públicas, a baixa valorização do magistério, com salários insignificantes destinados aos(às) professores(as), além da desqualificação do atendimento necessário e especializado oferecido às pessoas com deficiência, aos constrangimentos sofridos pelos diferentes na ótica da diversidade, é urgente que medidas sejam adotadas para que o direito à Educação, à Cultura, ao Esporte e ao Lazer seja destacado e respeitado. Considerando a perversidade em adotar uma postura equivocada de culpabilização da criança por seus fracassos, essa idéia, à luz dos direitos constitucionais, extrapola os muros locais e globais das instituições educacionais quando analisa as transformações das teorias, dos projetos pedagógicos e psicopedagógicos que pretensamente poderiam ser desenvolvidos frente a compreensão do papel da escola, dos professores e das famílias. O que provoca o fracasso do aluno na escola? Preferimos chamar de (in)sucesso escolar dos alunos, que aparece cristalizado sob forma de repetências e evasões, que se constituem uns dos fatores contribuintes para a exclusão social.

Discutir fracasso escolar no ponto de vista do aluno é desacreditar nas potencialidades inerentes ao ser humano e em sua capacidade de aprender. Nesse aspecto de garantias sociais, a discussão é mais ampla, tem como cenário as oportunidades sociais e as condições de vida dadas ao sujeito e as dimensões de suas 
perdas pessoais e sociais, frente à qualidade de vida que lhe é oferecida desde o seu nascimento. Pensamos em discutir aqui algumas idéias que achamos importantes não só para a compreensão do (in) sucesso dos alunos, mas sobretudo por serem idéias capazes de provocar reflexões e mudanças nas atitudes profissionais, daqueles que lidam com o tema. Muitos alunos, ao ingressarem na escola não se adaptam à realidade e exigências dela.

A escola por sua vez, não considera como válido o repertório de aprendizagens que o aluno traz de seu cotidiano, enquanto cidadão advindo dos mais diversos e comprometidos contextos sociais. Embora seus desempenhos até então tivessem sido suficientes na vida fora da escola, são considerados agora, inadequados, com uma linguagem insuficiente e uma resposta educativa abaixo dos padrões esperados pela escola. Os alunos, por não adquirirem e produzirem os conhecimentos necessários às atividades escolares, são considerados incompetentes ou com baixo rendimento escolar. A escola não está preparada para receber os alunos que representam uma diversidade cultural ou que difiram do aluno padrão.

O sentimento de incapacidade e as dificuldades em aprender, provocam as evasões da escola logo nas $1^{\text {a }}$ séries do ensino fundamental. Tais alunos, vão constituir no futuro os números da estatística da economia informal, sobrevivendo como biscateiros, catadores, etc, enfim, prestadores de serviços gerais, que representam a mão - de- obra barata e desqualificada.

O papel da escola hoje, como responsável também pela vivência da cidadania plena, seria intervir nos processos responsáveis pela evasão da criança da escola, tanto oferecendo uma melhor formação e qualificação de seus profissionais como difundindo meios de tornar o ensino instigante, interessante e desafiador, capaz de manter o aluno ocupado, pelo tempo necessário à sua preparação para a vida e para o trabalho, com uma educação de qualidade.

Um tema provocativo e desafiador como este, nos leva a pensar na responsabilidade da nação, do Estado em suas diversas instâncias entre elas a Escola, os professores e os pais, que mais imediatamente, são responsáveis pelos caminhos da educação dos alunos sob sua responsabilidade. Refletir sobre essas questões, já é um primeiro passo na busca de minimizar o problema.

Ao analisar todo o processo que constitui o (in) sucesso escolar, a partir da incapacidade da Escola tanto em formar profissionais capazes de identificar e entender as dificuldades de aprendizagem dos alunos como em avaliar o "real" potencial dos 
alunos, faz-nos logo perceber a distância, entre o conhecimento formal oferecido pela escola e o conhecimento prático(informal) que o aluno já dispõe, “traz” de casa. É preciso, antes de tudo, considerar este corte, estabelecido entre os conteúdos formais (da escola) e os conhecimentos informais, trazidos da prática, da realidade (dos alunos).

Por outro lado, as formas de avaliação da aprendizagem, insistem explicitamente ou implicitamente, em ignorar os processos de construção do conhecimento do aluno quando estes o expressam com palavras não enquadradas no código linguístico formal, acadêmico. Desta maneira, logo estes alunos são rotulados de "bons", "maus", “fracos" e "fortes", “aptos" e "inaptos". Carvalho (2000) diz:

As previsões sobre o futuro desses alunos pareciam relacionar-se, porém, muito mais à prática discursiva (re)construída e negociada por eles e pela professora, a partir de seus contextos culturais do que às diferenças econômicas. A cultura escolar, em geral hegemônica e rotuladora, se confrontaria diretamente com as outras formas de interação social e discursivas trazidas pelos alunos (CARVALHO, 2000, p. 31).

O (in) sucesso escolar expressado sob a forma de evasões e repetências, logo aparece para os alunos economicamente menos favorecidos. Para cada aluno que fracassa na Escola, variáveis diversas são responsáveis. Collares e Moyses(1986:8) analisam o fracasso escola "um complexo jogo de fatores educacionais, sociais, culturais e econômicos, que refletem a política governamental para o setor social. Este artigo de Collares e Moyses foi escrito em 1986, portanto, 29 anos atrás, cabe então uma pergunta: o que mudou durante este tempo, na sociedade brasileira, na escola? Quase nada, continuamos com centenas de crianças fora da escola, pois estamos cada dia mais pobres.

Uma infinidade de fatores colabora para este empobrecimento: o desemprego, o achatamento salarial, os cortes no orçamento público exatamente para as verbas destinadas às questões sociais, como atenção à saúde, às necessidades educacionais, etc. Pouco se fez por nossas crianças, continua o trabalho infantil, pela necessidade de "ajudar" ou até "sustentar" integralmente a família, continua a escola desinteressante, despersonalizadora. Colocamos aqui uma crítica, despersonalizadora no sentido de comprometer a formação da identidade da criança.

A criança que consegue chegar à escola, não é nem "dona" de seu material didático, em particular de seu livro, que não pode riscá-lo, tê-lo como seu. As campanhas “educativas” do MEC, veiculadas na mídia (sobretudo na televisão) dizem 
que deve zelá-lo, não por ser útil, seu, mas pelo fato de ser este livro usado depois por outras crianças. Será mesmo que o governo que gasta tanto em outras coisas, como propaganda de seus "feitos", em horários nobres da televisão, por exemplo, não tem verbas para comprar livros para todas as crianças? Note-se que em algumas escolas a criança não leva sequer o livro para casa, tem que deixá-lo na escola para ser utilizado em outro horário, por outra turma. Com certeza, é uma forma perversa e punitiva de economizar para a renda do país, sobretudo um governo que tem como um dos lemas o direito constitucional de "garantia de acesso e permanência para todos na escola".

A escola recebe a cada ano, um quantitativo de alunos que detém, por sua própria origem e realidade de vida, marcas que os tornam diferentes. São crianças advindas de contextos sócio-econômicos e culturais que comprometem seu desenvolvimento harmonioso. A escola parece não enxergá-los e trata-os por igual, oportunizando o surgimento dos grupos de alunos bem sucedidos (que certamente tiveram melhores oportunidades de estimulação anteriores à entrada na escola) e os grupos de alunos fracassados e que tem na escola suas únicas, e às vezes até as últimas, oportunidades de acesso ao saber). Estes últimos, fortalecerão a manutenção da organização social que os rotulou e a escola continuará impotente para tentar igualar o que a realidade social distingue. Será que é este o papel da escola? De elemento de nivelamento social? Ou devemos assumir que a sociedade não oferece oportunidades iguais para todas as crianças? Constatar a necessidade de democratizar o ensino e lutar pela ampliação de vagas na Escola, pode não ser o melhor caminho na tentativa de oferecer oportunidades iguais para todos. A Escola Pública, gratuita e obrigatória, não assegura o caráter democrático. Numa consideração à teoria de aptidões, a Escola parece camuflar a desigualdade da sala de aula, onde os "fracassados" em geral são os “carentes”, as crianças de classes populares, cujos resultados de contínuos (in)sucessos, acarretam para Educação, números cada vez maiores de evasão e repetências.

O trato autoritário da Escola, nas questões do fracasso escolar, merece análise também do ponto de vista da dependência inicial da criança pelo adulto. A inquestionável autoridade onde "professor manda e aluno obedece", "professor ensina, aluno aprende" e outros tantos posicionamentos que mostram um distanciamento afetivo e pessoal, na relação professor aluno. Este comportamento é comum em todos os grupos sociais no cotidiano das escolas.

A superação do (in)sucesso escolar requer novas formas de avaliar o aluno, novas formas de entender os processos de aprendizagem. São questões estritamente 
individuais, embora se dêem no coletivo da sala de aula. É preciso que a escola, seus professores, equipe técnica e diretores, assumam a dimensão social que o ato educativo representa.

As diferentes formas de obtenção do saber, advém mais facilmente, com a adoção de metodologias diferenciadas no trabalho pedagógico. A pesquisa, como um recurso pedagógico, vivenciado logo nas séries iniciais, permite que o aluno seja o construtor de seu próprio saber, que possa dirigir sua própria aprendizagem com autonomia, através da busca, da curiosidade e criatividade que o processo de investigação desperta.

A iniciação de estudantes em projetos de pesquisa, de acordo com seu nível de escolaridade, traz para eles a oportunidade da formação da atitude de descobrir, de investigar, de envolver-se em aspectos básicos para o desenvolvimento de qualquer investigação em torno de um problema, para o qual se busca um maior número de respostas.

Embora saibamos que, as diferentes respostas dadas pelos alunos, não necessariamente significam capacidades ou incapacidades deles em aprender, é preciso que a ação pedagógica reconheça e tenha mais espaços dinâmicos de aprendizagem, respeitando e compreendendo os diferentes ritmos, as diferentes formas de construções de conhecimento de seus alunos, e, a pesquisa pode tornar-se uma grande aliada de alunos e de professores nos processos de ensino-aprendizagem.

A Escola, reproduzindo a estrutura social através do ensino de hábitos e valores aceitos socialmente, seleciona aqueles alunos cujas respostas individuais, não a satisfez. Eles são avaliados então por padrões onde as diferenças culturais e sociais confundemse com deficiências intelectuais.

Por outro lado, a escola tem seu discurso pedagógico fragmentado, as atividades oferecidas pouco se aproximam da realidade de seus alunos, embora já se perceba em muitos educadores a preocupação com o resgate da totalidade, da apreensão do aluno concreto, situado num determinado contexto histórico: ele, a comunidade onde vive e as relações que estabelecem, num contexto mais amplo de análise. Para Klein (1997):

[...] no discurso dos educadores, a discussão acerca da fragmentação e da totalidade se assenta, enfaticamente, em dois aspectos: no aluno e no conteúdo. Em outros palavras, tem-se insistido na necessidade de que tanto o aluno quanto o conteúdo sejam aprendidos enquanto totalidade (p. 57) 
E que conteúdos são esses? Que realidade é essa? O aluno não se "vê" na escola, não se sente parte dela, não domina nem a linguagem dos professores, nem a linguagem dos textos dos livros didáticos que às vezes, retratam até uma região geográfica diferente da sua.

Considerar a pluralidade e diversidade dos alunos, seria uma forma de minimizar os problemas de aprendizagem? Uma reordenação de conteúdos seria a solução? Pensamos que, enquanto não houver uma preocupação em facilitar a aquisição, compreensão, elaboração e produção do conhecimento por parte do aluno, que, ativamente e interativamente, deve ser capaz de refletir sobre o que aprendeu, generalizando suas experiências pedagógicas, entenderemos, porque alunos repetentes, lentos e com comportamento social diferente, que apresentam um vocabulário simples composto por poucas palavras (em geral, termos do convívio familiar) com muitas gírias e vícios de linguagem, são aqueles que são encaminhados aos programas especiais.

Por sua vez, as famílias dos alunos egressos das classes populares, geralmente aqueles que detém os (in)sucessos escolares - não percebem a sucessão de disfarces sociais e mascaramentos educacionais que os impedem de vivenciar a plena democracia no contexto social do qual fazem parte.

A inclusão de novas metodologias didático-pedagógicas, a informação e a discussão de uma proposta de trabalho pedagógico continuado, sistematizado, na qual os diferentes níveis de ensino não sejam uma crescente sequência de obstáculos ameaçadores que o aluno apto ou não, preparado ou não, tem que superar.

Esperamos que este estudo, tenha contribuído para evidenciar alguns pontos, que formam um conjunto de fazeres e de dizeres pedagógicos, que permitem construir análises e ajustes ao ato pedagógico, como por exemplo, o cuidado do professor em corrigir ou prevenir a circulação de informações distorcidas ou aprendidas parcialmente por seus alunos, revelando o contexto sócio-econômico e cultural que se originam, que a inabilidade ou falta de domínio do aluno para executar determinada tarefa seja contornada pelo preparo profissional do professor competente e comprometido, capaz de lidar com as dificuldades de seus alunos.

Não se pretende aqui encontrar soluções mágicas para o (in)sucesso escolar, mas espera-se que as responsabilidades de refletir criticamente sobre estas questões, favoreçam algumas transformações na escola e nos que dela fazem parte. Se isto 
acontecer, já se terá dado alguns passos para que os equívocos, os rótulos observados e atribuídos aos alunos sejam pelo menos discutidos.

Com um novo olhar da Educação, profissionais ligados aos atendimentos especializados de prevenção e estimulação, se propõem a construir um olhar integral sobre a dificuldade em aprender ou apresenta deficiência ou descompassos em seu desenvolvimento.

Discutir, com propriedade, à luz das teorias cientificas, as desigualdades sociais responsáveis pelo desagrupamento das crianças com alguma deficiência, com transtornos invasivos do desenvolvimento, com mobilidade reduzida e outras síndromes, crianças em situação de vulnerabilidade social, a partir de concepções mais colaborativas entre os diversos segmentos sociais que organizados em parcerias, os profissionais com tais aportes, poderiam vir a configurar um novo contexto de desinstitucionalização para questões amplas e especificas da aprendizagem que envolvem os segmentos sociais daqueles sujeitos considerados menos favorecidos.

Os profissionais que lidam com essa parcela da população, numa atitude geradora e multiplicadora de ações mais positivas, efetivariam situações minimizadoras de conflitos, que se instalam com a desinformação e discriminação para os sujeitos partícipes desses segmentos sociais, quando se constroem para eles preconceitos, desalento e desconfiança em suas capacidades individuais de aprendizagem. Vitimizar a criança ou adolescente com alguma diferença, vislumbra a importância do trabalho competente e qualificado em todos os espaços institucionais ou não.

O desenvolvimento das ciências e a apreensão dos conhecimentos organizados, representam abordagens científicas que, uma vez experimentadas, farão surgir através da sociabilização, avanços e também retrocessos que certamente favorecerão o surgimento de ações mais otimizadoras pertinentes e atuais e que terão como desdobramentos, o atendimento especializado, qualificado e potencializador de pessoas que fazem parte do universo da discriminação, do preconceito e da inclusão escolar.

Sabemos que as instâncias institucionais ainda atendem as necessidades de uma minoria que no contexto econômico globalizado gravita na produção da miséria; da marginalidade; da negação de acesso aos bens públicos e também da Escola

As dificuldades de reconhecer o outro, nas idéias de Costa (2008), configuramse mundialmente; em 852 milhões de desnutridos, 2 bilhões são de excluídos de habitação, saneamento e alimentos 
No Brasil, a inclusão tem suporte constitucional (1988) nosso ordenamento jurídico fundamenta: cidadania e dignidade humana (artigo $1^{\circ}$ ). Promoção do bem de todos, sem preconceitos ou discriminação (artigo 3) Igualdade de condições de acesso e permanência na escola (artigo 206) Constitucionalmente, a Educação é dever do estado, efetivado com a garantia de acesso aos níveis mais elevados de ensino, pesquisa e criação artística (artigo 208).

Mas para que tais premissas aconteçam, é preciso que os próprios profissionais se reconheçam como sujeitos culturais, mediadores e potencializadores da educação articulando a cultura dos alunos ao conhecimento escolar. Acreditamos que a função do psicopedagogo, no assessoramento desse docente, tanto na sua formação inicial e continuada, imbrica para as necessidades formativas do saber fazer, de priorizar valores éticos, sensibilidade, criatividade, da estimulação do espírito crítico do aluno, difundindo o conhecimento construído pelas reflexões, resgatando o sentido político da ação formativa educativa.

Os papeis sociais vivenciados pelos educadores, em seu aspecto socializador, situa-se no interior dos grupos humanos, mobilizando instrumentos de comunicação e transmissão para as novas gerações, das conquistas sociais e processos de educação, nos grupos de trabalho e produção. Para tanto, ao longo da história, diferentes formas de transmissão de conhecimentos foram usadas e a função da escola, configurada para transmissão do conhecimento com seus conteúdos, sistemas de organização apresentados às novas gerações, assume aspectos tradicionais para garantir a reprodução social e cultural.

A inculcação e as ideologias, propaladas de forma sutil, sinuosa e subterrânea, representações sociais objetivas e subjetivas efetiva a culpabilização do aluno quando o responsabiliza pelos seus fracassos por questões orgânicas, econômicas ou culturais.

Nesse sentido, o trabalho pedagógico se constitui numa teia de relações ampliando ou reduzido focos de analises das práticas sociais, diluídos em teorias, currículos e condutas numa aprendizagem acadêmica seletiva. A convivência de um currículo comum, a diversidade pedagógica, a atenuação dos efeitos da desigualdade, pluralidade de formas de viver, pensar e agir, expressão genuína da comunidade humana, provoca e facilita a reconstrução do conhecimento.

A Escola, enquanto espaço formal de garantia de acesso à educação de qualidade, ao esporte, à cultura e ao lazer, passa a fazer parte integrante e importante na 
Rede de Proteção à Infância e Adolescência, constituída a partir do Estatuto da Criança e do Adolescente, como é possível visualizar nos Art. 55 e 56.

Art. 55. Os pais ou responsáveis têm a obrigação de matricular seus filhos ou pupilos na rede regular de ensino.

Art. 56. Os dirigentes de estabelecimentos de ensino fundamental comunicarão ao Conselho Tutelar os casos de:

I-maus-tratos envolvendo seus alunos;

II-reiteração de faltas injustificadas e de evasão escolar, esgotados os recursos escolares;

III-elevados índices de repetência.

Os maus-tratos a que se refere o inciso I são relativos à ação da família, da sociedade e Estado e nem sempre são facilmente percebíveis. É preciso compromisso, envolvimento e dedicação à causa da infância e da adolescência para tornar visível a prática dos maus-tratos que, em geral, tem início nas relações de poder que se encontra nas famílias.

Esta forma de conceber a escola direciona a importância do investimento do Estado nas políticas de Educação e Cultura: ampliação da rede de ensino público e de qualidade para todos(as) os(as) que dela necessitarem, adequação dos currículos à realidade local, respeitando os ritmos e processos dos(as) estudantes, suas culturas e possibilidades, oportunizando a educação continuada e permanente ao(à) professor(a), bem como o acesso à cultura, capacitando-os(as) para responderem às demandas do complexo cotidiano da educação. Sem destinação de parcela significativa dos recursos para a Educação, Cultura, Esporte e Lazer, esse direito estará fadado ao fracasso. Sua garantia, no entanto, encontra-se respaldada no art. 54 do Estatuto da Criança e do Adolescente.

O direito à cultura, à educação, esporte e lazer é direito humano porque a necessidade de se expressar, manifestar pensamentos e valores é intrínseca à condição humana. Vivemos tempos onde os espaços culturais para manifestação são escassos, onde a cultura se mercantilizou e somente tem acesso quem pode pagar por um ingresso de cinema e teatro. Porém, há toda uma dinâmica cultural onde diversos grupos sociais, a partir das suas próprias percepções e referenciais, criam cidadania cultural.

A arte, lazer e esporte é a linguagem mais compreendida pelos jovens e tem se tornado instrumental importante para a construção da cidadania desses grupos. Pessoas 
com de deficiência, negros, homossexuais, ciganos, mulheres e idosos, vêm também encontrando no esporte e na cultura razões para expressar a sua própria singularidade.,

A educação é um direito humano e meio indispensável para realizar outros direitos, como os individuais e sociais. É referencial para a construção de conhecimentos, desenvolvimento de valores, crenças e atitudes em favor de uma sociedade mais humanizada. Todos os processos educativos devem estar direcionados ao pleno desenvolvimento humano e de suas potencialidades

Eduardo Galeano, em "A cultura do terror", cita que a extorsão, o insulto, a ameaça, o cascudo, a bofetada, a surra, o açoite, o quarto escuro, a ducha gelada, o jejum obrigatório, a comida obrigatória, a proibição de sair, a proibição de se dizer o que se pensa, a proibição de se fazer o que se sente, a humilhação pública, são alguns dos métodos de penitência e tortura tradicionais da família. Esta afirmação reafirma o papel da educação preventiva integral na escola.

A este respeito, o Laboratório de Estudos da Criança (Lacri), do Instituto de Psicologia da Universidade de São Paulo, divulgou a Petição por uma Pedagogia Não Violenta: Toda criança tem direito de ser educada sem violência, seja física, psicológica ou sexual. A criança precisa aprender com palavras e atitudes de compreensão e respeito e não com empurrões, safanões, tapas, humilhações...

Naturalmente, essa postura não significa sermos contra a necessidade de disciplina e limites na educação infantil. Significa, isso sim, que repudiamos o uso da violência como estratégia de educar as novas gerações, mesmo que esta violência assuma a forma de um tapa (ainda tão defendido na pedagogia familiar) ou de castigos físicos e/ou degradantes (ainda adotados em escolas e instituições ditas de proteção da infância). Por isso, defendemos o princípio de que se queremos um mundo não-violento, devemos começar educando sem violência as futuras gerações!

Os arts. 205, 206 da Constituição da Republica Federativa Brasileira /88 estabelecem que a educação, direito de todos e dever do Estado e da família, será promovida e incentivada com a colaboração da sociedade, visando ao pleno desenvolvimento da pessoa, seu preparo para o exercício da cidadania e sua qualificação para o trabalho.

O Estatuto da Criança e do Adolescente/1990, com vistas a cumprir os preceitos constitucionais assegura à criança e ao adolescente preferencialmente uma educação voltada ao integral desenvolvimento da pessoa, com prática para a cidadania 
de forma clara e objetiva e capacitação para o trabalho, sempre preconizando o absoluto respeito aos direitos fundamentais das crianças e dos adolescentes.

O ECA no Art. 57, determina que o poder público estimulará pesquisas, experiências e novas propostas relativas a calendário, seriação, currículo, metodologia, didática e avaliação, com vistas à inserção de crianças e adolescentes excluídos do ensino fundamental obrigatório.

No art. 58.o ECA explicita que no processo educacional respeitar-se-ão os valores culturais, artísticos e históricos próprios do contexto social da criança e do adolescente, garantindo-se à estes a liberdade de criação e o acesso às fontes de cultura.

Afirma também o ECA em seu art. 59 que os municípios, com apoio dos estados e da União, estimularão e facilitarão a destinação de recursos e espaços para programações culturais, esportivas e de lazer voltadas para a infância e a juventude.

Para cumprimento destes artigos, faz-se necessária uma política integrada das Secretarias de Educação, da Cultura, do Esporte e da Ação Social, no âmbito municipal, bem como no estadual e no federal, de tal forma a garantir o atendimento integral da criança e do(a) adolescente, no que tange aos seus direitos fundamentais. Infelizmente, o que se vê, são ações isoladas, quando existentes, muitas vezes contraditórias, denunciando a inexistência de políticas públicas que respeitem a criança e o(a) adolescente como prioridade absoluta.

Isto também se verifica no processo educativo e cultural para além da escola. As famílias das classes populares apresentam baixa escolaridade e pouco acesso à cultura, o que acaba reforçando nessa e nas futuras gerações a dependência ao Estado para a sobrevivência, para o pensar, para o agir.

Nas entidades de abrigo, relativo ao Direito à Educação, à Cultura, ao Esporte e ao Lazer há, quase que exclusivamente, a garantia da escolaridade, com dificuldades de acesso prioritário à saúde, às atividades esportivas diversificadas, aos bens culturais e a diferentes formas de lazer.

O Direito à Educação, à Cultura, ao Esporte e ao Lazer é um baluarte do movimento dos direitos humanos na medida em que garante à criança e ao(à) adolescente o acesso ao conhecimento histórica e culturalmente construído, permitindolhe o desenvolvimento integral. Tendo por base os pilares da educação preconizados pela UNESCO para o século XXI, pela Educação, Cultura, Esporte e Lazer fica assegurada à criança e ao(à) adolescente a oportunidade de aprender a SER, de aprender a Conhecer, de aprender a Fazer, de aprender a Conviver e também de aprender a 
Sonhar, aprendizagens essas precursoras das competências nas dimensões pessoal, cognitiva, produtiva, social e relativa ao projeto de vida.

Atualmente, a existência de organizações não-governamentais (ONGs), bem como de Organizações da Sociedade Civil de Interesse Público (OSCIP) têm substituído o Estado em suas ações essenciais: oferecer um pouco de dignidade à vida das crianças, bem como o direito à educação de qualidade para que possam exercer plenamente sua cidadania.

Como minimizar a distância entre o que se acredita ser possível fazer e o que ocorre na prática? Como auxiliar os professores a retomarem seu papel educador e transformarem sua prática? Como mobilizar os meninos a acreditarem que a escola vai fazer a diferença significativa em suas vidas e em seus projetos de futuro? Como a universidade brasileira pode contribuir com as políticas públicas de inclusão a partir da formação permanente dos professores? (ASINELLI-LUZ, 2005, p. 201).

Os direitos da criança e do(a) adolescente são soberanos, não podendo ser violados ou ameaçados. Mesmo à revelia da criança e do(a) adolescente, têm que ser respeitados. No caso de violação ou ameaça cabe ao Conselho Tutelar receber a queixa, encaminhar o caso e fazer a devida notificação no Sistema de Informação para a Infância e Adolescência - SIPIA.

O SIPIA estabelece três condições básicas para caracterizar uma violação de direito:

a) A existência de um sujeito de 0 a 18 anos que tenha sofrido a violação;

b) A prática de uma ação contrária ao direito assegurado, ou mesmo a ausência da ação necessária ao cumprimento do direito assegurado;

c) Um(a) responsável pela ação ou pela omissão que resultou no descumprimento do direito (pais ou responsáveis, o Estado, a sociedade e a própria criança ou adolescente, em decorrência de sua conduta).

As violações mais frequientes ao Direito à Educação, à Cultura, ao Esporte e ao Lazer foram agrupadas em seis indicadores, a saber:

1.Impedimento de acesso à educação: falta de escola, falta de vagas, falta de oferta de ensino noturno regular ao(à) adolescente trabalhador(a), incompatibilidade do calendário escolar com as atividades socioeconômicas e inexistência de ensino fundamental completo.

2.Impedimento de permanência no sistema escolar: punições abusivas, critérios avaliativos discriminatórios, expulsão indevida e constrangimento de qualquer espécie. 
3.Ausência ou impedimento de acesso à creche ou pré-escola (ciclo inicial): falta de creche ou pré-escola, falta de vagas em creche ou pré-escola, não-cumprimento, por parte das empresas, da obrigatoriedade da creche, falta de equipe especializada para atendimento de criança de 0 a 6 anos, distância física entre empresa/creche ou casa/creche e distância física entre empresa/pré-escola ou casa/pré-escola.

4.Ausência de condições educacionais adequadas: ausência de merenda escolar, professores(as) despreparados(as), falta de segurança nas escolas, ausência de serviços especializados, alto índice de repetência, ausência de informações aos pais sobre a freqüência, interrupções sistemáticas do processo de ensino, falta de material didático, condições insalubres dos estabelecimentos escolares e impedimento de acesso aos critérios avaliativos.

5.Ausência ou impedimento de uso de equipamentos de cultura, esporte ou lazer: ausência de equipamentos e programas de esporte, lazer e cultura, falta de manutenção dos equipamentos existentes, falta de segurança nos locais destinados à cultura, ao esporte e ao lazer, impedimento do uso de equipamentos e espaço de lazer existentes.

6.Atos atentatórios ao exercício da cidadania: ausência ou impedimento de acesso à meios de transporte, impedimento de acesso à escola, restrição ao direito de organização e participação de entidades estudantis; não comunicação ao Conselho Tutelar de situação de maus-tratos, excesso de faltas injustificadas, evasão escolar ou elevado índice de repetência, impedimento legal de garantias educacionais às crianças indígenas.

Quero aqui ressaltar a importância do(a) Pedagogo(a) no processo de mediação entre a criança, o(a) adolescente e a escola, visando à melhoria da qualidade de vida de todos os envolvidos no contexto educacional, crianças, adolescentes, professores(as), pais, mães e familiares responsáveis pela atenção e promoção da infância e adolescência cidadã. Cabe ao Estado efetivá-la e à Rede de Proteção monitorá-la.

\section{Algumas considerações intermediárias}

No atual momento da escola, da educação do país, necessário se faz refletir sobre as práticas pedagógicas trabalhadas nas salas de aula, no cotidiano do universo escolar, observando quais as necessidades para redirecionar os processos de ensino e aprendizagem. 
Provocar um debate, sobre a importância das formas de atuação dos pedagogos, dos psicopedagogos, dos psicólogos, dos professores frente a complexidade do ato educativo é fundamental quando se pretende dar uma melhor qualidade na dinâmica escolar. Refletir sobre os processos de avaliação, diante do conjunto de relações sociais, entendendo o significado político da avaliação e as contradições encontradas no ambiente escolar, faz lembrar Freire (1996:142) quando diz: "A ideologia tem que ver diretamente com ocultação da verdade dos fatos, com o uso da linguagem para penumbrar ou opacizar a realidade ao mesmo tempo em que nos torna míopes".

A cada ano, diminuem os recursos do governo federal para a educação e vem sendo transferidos para os Estados e Municípios, a implantação e execução das atividades escolares, sem haver por parte do governo federal, responsável pelas políticas traçadas para a educação, a preocupação com as condições econômicas, pedagógicas e sociais, que estes governos estaduais ou municipais têm, para oferecer uma educação de qualidade, ao contingente de seus estudantes. A falta de investimento na educação, em todos os níveis faz surgir um número de profissionais despreparados que por sua vez preparam mal seus alunos.

Os psicopedagogos, numa atitude geradora e multiplicadora de ações mais positivas, efetivariam situações minimizadoras de conflitos, que se instalam com a desinformação e discriminação para os sujeitos partícipes desses segmentos sociais, quando se constroem para eles preconceitos, desalento e desconfiança em suas capacidades individuais de aprendizagem. Vitimizar a criança ou adolescente com alguma diferença, vislumbra a importância do trabalho psicopedagógico em todos os espaços institucionais ou não.

Alguns pontos estimulam nossa discussão: como desenvolver um processo formativo que reconheça a educação como espaço de formação do humano?

Que medidas de superação dos entraves na escola, oportunizam a concretização de uma prática psicopedagógica democrática e inclusiva?

Que elementos de influência dos modelos formativos favoreceriam a formação continuada enquanto uma busca individual realizada no coletivo?

Como a Pedagogia, Psicopedagogia e a Psicologia podem auxiliar a Educação, na construção de novas atitudes docentes éticas, sociais e pedagógicas? 
Pensamos que essa atuação conjunta e intercomplementar com a Educação viabiliza os processos de inclusão social, cultural e digital. As atividades interdisciplinares tendo como foco a minimização da marginalização na sociedade informatizada, aponta também para a formação de professores/as com novos significados, novas exigências sociais. Parece-nos e a sociedade vem nos mostrando, a necessidade do surgimento de novos saberes para a prática educativa.

Neste sentido, mobilizando esses saberes, a Educação, a escola e aqueles que com elas colaboram, serão capazes de trabalhar à favor da inclusão e da diversidade, executando as políticas públicas para práticas educativas menos excludentes, reconhecendo as diferenças sem inferiorizá-las e superando os preconceitos, entendendo e reconhecendo o outro, partilhando e acolhendo sem nenhuma forma de discriminação.

Um destaque importante no processo formativo desses profissionais em particular, deverá ser manter um enfoque integrado de investigação e pesquisa com articulação imediata, teoria-prática nas ações psicopedagógicas na sala de aula, na escola e/ou em espaços não formais de educação.

Caberia às agências de formação, reforçar nos currículos dos cursos, espaços para estimular o estudo e a pesquisa, através das atividades planejadas com os/as alunos/as, oportunizando a vivencia em sala de aula e nas comunidades envolvidas de ações afirmativas de inclusão e respeito à diversidade.

Uma questão se coloca como norte: como se capacita um/a educador/a, dentro de uma dinâmica social que sabemos ser movida por fatores econômicos, sociais e políticos e cuja meta é a formação do humano? É nosso interesse, analisar a formação do humano, como um dos aspectos fundamentais da educação e diversidade, a partir do estudo dos processos formativos dos profissionais que atuam na escola e a partir da constatação das várias direções da trajetória formativa e profissional de um/a psicopedagogo/a.

Parece-nos que quanto mais clara for a visão, quanto mais definida for a compreensão dos espaços profissionais que um profissional da Educação pode ocupar, mais há a necessidade de conhecer as ciências pedagógicas ancoradas em seus Códigos de Ética, sobretudo quando explica a área de estudo e os diversos espaços de atuação no contexto de Saúde e Educação.

É importante para o profissional da Educação compreender o processo da aprendizagem humana; as condições normais e patológicas da aprendizagem, o contexto familiar, a escola, transitarem nos espaços formais e não formais onde a escolarização 
pode acontecer, tais elementos constituem-se os procedimentos específicos da Educação. Analisando e discutindo os fenômenos da aprendizagem à luz desses elementos e considerando o desenvolvimento psicossocial- educacional e físico da criança e do adolescente, estes profissionais, juntos, podem sem sombra de dúvida, minimizar os problemas de aprendizagem, tão comum hoje em nossas escolas.

Nos processos formativos dos profissionais que lidam com o desenvolvimento humano, verificamos a existência de vários fatores intervenientes, entre eles, a influência de vários modelos formativos, das dificuldades dos mercados de trabalho, da (des)valorização profissional e outras questões como gênero e classe. Tais questões tem influenciado, desde então, os caminhos de uma educação mais tolerante e inclusiva.

Todos os seres humanos constroem conhecimentos de várias maneiras e por diferentes razões. As experiências cotidianas vivenciadas criadas pelos indivíduos constituem-se espaços de aquisições de conhecimentos. Nessa perspectiva, a profissão docente tem um conhecimento específico, que é utilizado e transmitido no ato de ensinar e aprender, de uma geração para outra, de transmitir o conhecimento produzido em diferentes manifestações e formas de expressão. Assim, pensamos que reconhecer nos alunos, os saberes que trazem já construídos em diferentes espaços e nas suas relações cotidianas, é reconhecer as aprendizagens, as vivenciadas sociais, estimular transformações desses saberes em conhecimentos, respeitando sobremaneira os níveis de escolarização e considerando as aquisições e habilidades que os alunos já dispõem considerando as relações entre os profissionais da educação, como aprendentes e aprendizes convivem, ambos, em espaços não formais de educação e escolarização.

Bossa (2003) e outros autores justificam a necessidade social do reconhecimento profissional, do/a profissional psicopedagogo/a, fato recente, acontecido no Congresso Nacional, conforme ao PLC 31/2010, aprovado em 5 de fevereiro de 2014, que regulamenta a profissão do psicopedagogo, a partir das especificidades da profissão que ele/a demonstrará na execução dos saberes e de competências do desempenho de seu trabalho.

A profissionalização de um/a profissional da educação, é uma busca difícil, complexa mas possível se perseguida através de atitudes de valorização da pesquisa no processo formativo, da socialização de resultados e de estudos psicopedagógicos que consolidam um modelo, um caminho de profissionalização que se espera obter, uma profissionalização capaz de preparar o/a psicopedagogo/a, para conviver e trabalhar 
com a diversidade nos diversos espaços sociais, o/a instrumentalize para o exercício de uma prática profissional responsável e inclusiva.

O reconhecimento do trabalho psicopedagógico é redimensionado em parcerias institucionais, que acenam para a construção de um status profissional distinto, que é construído no individual e no social que se articulam e se complementam, sobretudo quando pensamos em atividades psicopedagógicas integradoras entre a escola e a comunidade.

A construção de uma nova atitude ética, pedagógica, a escolha de ser um/a profissional com fazeres, dizeres, contradições e compromissos profissionais, uma maior mobilização do pensamento crítico, sinalizam as oportunidades de refletir sobre as práticas psicopedagógicas, do que fazem e porque fazem o trabalho educativo dentro de uma realidade social posta. Saviani (2003:21) diz: se para formar homens, é necessário um profundo conhecimento da realidade humana e se a realidade humana é essencialmente histórica, então o educador precisa dominar, precisa conhecer a história da diversidade. Daí, pensamos que, a ênfase na compreensão e aceitação dos diferentes contextos sócio históricos e econômicos dos alunos e suas famílias, podem significar as primeiras iniciativas para reconhecimento das diferenças e da diversidade.

Por outro lado, o desenvolvimento e cultivo, de sentimentos de responsabilidade e pertencimento, concretizam a necessidade de formar profissionais na ótica do humano. Boff (2001) nos inspira quando em seus artigos, comenta:

[...] a necessidade de zelar e cuidar de nossas crianças e adolescentes e apresenta a idéia de que cuidar é mais que um ato; é uma atitude.... abrange mais que um momento de atenção .... representa ocupação, preocupação, responsabilização e envolvimento afetivo com o outro (p. 33).

Pelas práticas do cotidiano vivenciado, percebemos que a partir da constatação das várias direções e espaços da trajetória profissional dos/as psicopedagogos/as, estes caminhos teóricos metodológicos, as posturas profissionais assumidas sofrem a influência de vários modelos formativos, da (des)valorização profissional e outras questões como gênero e classe e que tais questões, tem determinado desde então, os caminhos da profissionalização, sobretudo na perspectiva de uma educação mais tolerante e inclusiva.

A inclusão sócio educacional, que expressa a pluralidade e a diversidade, no âmbito da escola, passa por vários segmentos: a inclusão digital, que define hoje um 
quadro internacional de conexão à informação e ao conhecimento, visando evitar que pessoas e países fiquem à margem da sociedade informatizada, a exemplo disso, a ONU, segundo Monteiro (2001), passa a exigir que os países abram suas atividades econômicas, mercado, à tecnologia. Isto significa considerar o ciberespaço como uma rede comunicacional global. Neste sentido, os espaços virtuais encurtam as distancias do desconhecimento e da desinformação.

Situações como o uso de cartões eletrônicos, robôs, aparelhos eletrodomésticos, fotocopiadoras, fax, celulares, tv, dvd e computadores, representam a captura e apresentação de informações que os sujeitos sociais precisam dominar. Assim, cabe a escola passar aos seus alunos, todas as funções da informática, inserindo-os na sociedade informatizada, que para Levy (1996, p. 46) constituem-se: captura, digitalização, memória, tratamento e apresentação. São funções que na perspectiva geral de uma educação tecnológica oportunizará a inclusão dos alunos e da escola no mundo virtual. Para tanto, a formação do(a) psicopedagogo(a), na sociedade do conhecimento, implica numa relação entre os processos formativos e os novos significados trazidos à sociedade pela informatização e novas tecnologias.

A sociedade da informação, a sociedade do conhecimento, utiliza uma intensa rede de informática e telecomunicações, que disponibiliza com mais eficiência conhecimentos, ignorando fronteiras geográficas ou limites espaciais tornando a educação, mais que um processo de ensino e de aprendizagem. O/a psicopedagogo/a, como mediador/a das informações tecnológicas, precisa desenvolver suas próprias competências para lidar com o avanço das tecnologias. O uso de tv, vídeoconferencias, de retroprojetor, da pesquisa através das infovias, propicia nos cursos de formação de psicopedagogos, a aprendizagem de uma atitude investigativa construindo entre os(as) alunos(as), perfis de pesquisadores. Tais ações didático pedagógicas, inovam os contextos educacionais, renovam antigas práticas e permitem o acesso mais imediato às informações e à produção e disseminação do conhecimento.

Os desafios desta era tecnológica para as escolas e seus/as profissionais/as são inúmeros. Por outro lado, pensamos que é preciso rever os conteúdos dos cursos de formação de profissionais que lidam com a formação do Outro. A formação dos/as professores/as que atuam nas escolas, dos/as psicopedagogos/as que os assessoram, precisa passar por mudanças que implicam na formação do próprio homem. Freire (2002), na Pedagogia da Autonomia, apresenta o que ele considera os saberes necessários à prática educativa. Tais saberes, que aglutinam aspectos da docência 
enquanto especificidade da atividade humana, exigem rigorosidade, método, respeito, criticidade, ética, alegria e esperança, disponibilidade para o diálogo, tais questões sem dúvida representam uma prática pedagógica responsável pela formação de um(a) profissional comprometido com a mudança que a educação é capaz de promover.

Freire (1999) já antevisava a necessidade da educação e conscientização do homem, enquanto sujeito social, inserido numa realidade que ele deveria compreender e transformar. Cabe à escola e aos que nela atuam desempenhar este papel transformador, evitando uma prática bancária assumindo uma prática pedagógico-social que tem como suporte uma pedagogia da esperança, que liberta e faz pensar.

O/a professor/a à luz das idéias freireanas, é o outro, é aquele que entende a importância do ato de ler como uma leitura da vida como prática de uma liberdade de pensamento que liberta da opressão, descortinando o entendimento do mundo, das coisas e das pessoas, sem medo e com a ousadia que a educação como prática da liberdade inspira. Educação é mudança, é viver e aprender cada dia, através das ações de cultura e educação que podem ser desenvolvidas na escola da vila, na escola da vida.

Os termos inclusão, exclusão e diversidade expressam uma abordagem educacional, que vem se mostrando benéfica para os (as) que devem ser considerados cidadãos aceitos como iguais e também benéfica, para os considerados normais que conseguem exercitar a estruturação de suas personalidades, convivendo com as diferenças.

A proposta inclusiva, representa uma política pública na área da pesquisa e trabalho e de práticas educativas com atividades que precisam sair do discurso, romper com o caráter assistencialista e paternalista que sempre envolveu a educação para todos. A inclusão dos excluídos em todos os níveis de ensino, assume uma bandeira acima de tudo humanista e democrática.

A prática da compreensão e aceitação das diferenças e o respeito às deficiências, depende muito da conscientização, da sensibilidade, do respeito, do conhecimento dos processos de desenvolvimento, da aceitação e muito menos da legislação. Acreditamos que signifique, uma atitude construída, um engajamento individual, social e coletivo de superação de preconceitos.

Entendemos a educação e a diversidade como pontos de partida para que se constitua um processo dinâmico de muitas faces, desenvolvido através de um trabalho social e pedagógico onde a atitude de aceitação das diferenças, extrapola a simples 
colocação dos alunos com algum tipo de deficiência na sala de aula ou se estabeleçam cotas de inserção de minorias sociais nas Universidades.

Os princípios da diversidade e da inclusão podem ser compreendidos como a celebração das diferenças, da liderança, do direito de pertencer, da valorização da diversidade humana, da solidariedade, da importância das minorias, da cidadania e enfim, da qualidade de vida, do padrão de excelência dos resultados educacionais, da colaboração e cooperação com estratégias de apoio com novos papéis e responsabilidades, envolvendo todos que fazem a escola e os parceiros comunitários nos processos educativos.

Um dos aspectos mais significativos desta escola inclusiva, é a formação e capacitação de seus/as professores/as, de modo que, à esses/as professores/as sejam dadas condições práticas educacionais e pedagógicas de trabalhar com seus alunos com total participação na sala de aula.

Diante das discussões postas até aqui, o que é inclusão? Entendemos que antes de tudo é atitude, assim sendo, não pode ser imposta. É construída a partir da interiorização da aceitação, da ação colaborativa e da convivência com as diferenças, com a diversidade dos seres humanos. É a nossa capacidade de entender e reconhecer o outro, partilhando e acolhendo todas as pessoas sem exceção. Inclusão no respeito à diversidade para inclusão das minorias: dos/as meninos/as de rua, dos afrodescendentes, dos/as homossexuais, dos deficientes, dos ciganos, dos índios, dos idosos, das mulheres, enfim dos que representam um grupo vítima de opressão ou discriminação por qualquer motivo.

A escola deve ser o reflexo da vida da sociedade e como tal, deve viver a experiência de conviver com as diferenças. Um/a psicopedagogo/a preocupado/a com a formação do humano, na perspectiva da inclusão, na aceitação e reconhecimento da diversidade, precisa ser capacitado mas não precisa ser especialista em determinada deficiência. A escola cumpre seu papel, dando ao professor suporte pedagógico adequado com interpretes de sinais, tradutores de braille, através da construção de parcerias profissionais e institucionais, que poderão ser muito produtivas para seus(as) alunos(as) e para os (as) seus(as) professores(as) .

A escola precisa começar a atender aquele/a aluno/a que não é o/a ideal. Os/as alunos/as e os/as professores/as não podem ser reféns de um currículo pedagógico mal organizado, incoerente, que não abre espaço para o talento das crianças e quem não acompanha o conteúdo está fadado à exclusão e ao fracasso. 
A figura do psicopedagogo passa a ser entendida como aquele profissional atuante, que coordena as atividades educacionais otimizadoras, quando aliadas ao conhecimento proporcionado pela psicologia, pelas ciências da educação que trazem como conseqüência imediata, o sucesso do desempenho acadêmico do/a aluno/a, especialmente aquele/a que apresenta alguma dificuldade de aprendizagem, facilitando sua inserção na comunidade que vive.

As dificuldades de aprendizagem são questões vivenciadas diariamente nas escolas, despertando o interesse dos/as educadores/as e chamando a atenção para um grande número de crianças que freqüentam a escola e são traídas por suas dificuldades de adaptação, de metodologia ou de desenvolvimento desarmônico.

Por muitos anos estas crianças foram mal diagnosticas, maltratadas ou ignoradas. Muitas são negras ou vindas das camadas sociais mais comprometidas economicamente, rotuladas como lentas, preguiçosas, até deficientes, estes adjetivos escondem uma prática docente ineficiente ou desinteressada e uma escola que não atende as necessidades dos/as aluno/as ou ainda demonstra a falta de conhecimento dos que fazem a escola sobre a questão.

Muitos/as professores/as, ainda ignoram que crianças, adolescentes e adultos, podem apresentar algum problema de aprendizagem de ordem orgânica, psicológica ou social ou cultural.

Se admitirmos que a base para a aprendizagem são as necessidades individuais e que a força motriz da conduta humana são os motivos, as aspirações, desejos e interesses que se organizam em aprendizagens, estamos aceitando a idéia de que o conhecimento aprendido é advém de uma diversidade de necessidades que a maioria dos autores as dividem em: materiais, espirituais, biológicas e culturais. De tais necessidades derivam-se muitas outras, que implicam nas diversas formas de organização da sociedade, das questões da cultura e religião, das identidades dos grupos sociais e, sobretudo, nos sentidos de classe e raça entre os indivíduos.

Yershov (1999) agrupa as necessidades do homem em necessidades biológicas: sono, conforto, alimentação, de defesa, sobrevivência. Sociais: interação, afeto, carinho, aprovação, justiça, ideais. Conhecimento, informação e a cultura. Como percebemos, em se tratando de necessidades... somos todos iguais, precisamos então, reconhecer as diferenças dentro da igualdade na condição de seres humanos. 
O desenvolvimento sociocultural leva o ser humano à outras necessidades. Vigotsky (1999, p. 85) diz que "a ação do homem surge no processo de desenvolvimento cultural e histórico através de uma ação dirigida ao futuro".

A forma de ensinar extrapola a sala de aula, a observação do aluno para verificar suas aprendizagens, envolve brincar, ouvir, observar como se organizam diante do mundo, das coisas e das pessoas, demonstra a importância do trabalho psicopedagógico, que se evidencia no processo de observação, avaliação e intervenção, para minimizar as dificuldades dos alunos.

O/a professor/a, a família e a escola, envolvem aspectos socioculturais importantes para a aprendizagem. Ensinar e aprender, são questões complexas, exigem a participação da família e dos técnicos da escola, necessita de muita reflexão, além de configurar-se como um compromisso social e político e como anteriormente colocamos, implica em um conhecimento específico sobre as teorias e processos de aprendizagem. São inúmeras as contribuições do trabalho psicopedagógico, especializado e competente, no sentido de estruturar a construção ou reconstrução da aprendizagem dos/as alunos/as, compensando ou minimizando as limitações, ajudando o/a aluno/a, a dirimir ou conviver com suas dificuldades, reavaliando ou redirecionando suas necessidades.

Com objetivos multidimensionais, o/a psicopedagogo/a adota enfoques integrados de investigação científica e vivencias de práticas psicopedagógicas em suas atividades, trabalhando os aspectos preventivos e atuando como agente facilitador dos processos cognitivos, beneficiando os/a alunos/as sejam quais forem suas dificuldades

A questão da formação dos profissionais da Psicopedagogia, para atuarem junto a ed. inclusiva se torna um desafio quando se pensa na construção de um perfil profissional que possa ser adequado às exigências da demanda, tanto do mercado de trabalho quanto do exercício das práticas profissionais cotidianas, frente aos avanços da ciência, das inovações tecnológicas e da própria da sociedade.

As áreas de saúde e de educação, no aspecto formativo de seus profissionais, parecem ser as mais carentes, pois necessitam de atualização permanente de seu corpo de conhecimentos, de seus métodos, de seus procedimentos e de qualificação/ capacitação de seus profissionais, para acompanhar as técnicas inovadoras que constantemente surgem no cenário profissional e o percurso da produção do conhecimento, que por sua própria característica, é seqüenciado, cumulativo, dinâmico e 
em constante evolução. Rodrigues (2009) aponta para a necessidade de uma formação profissional não fragmentada e continua, com o domínio de teorias e práticas que tenham como objetivo entender como se aprende e entender por que não se aprende e a partir desse entendimento, o que fazer?

Avanços se dão, nos processos formativos, quando se planeja uma atualização contínua dos profissionais, no sentido de estimular e garantir os espaços que investigações acadêmicas, através de cursos que, distantes de conteúdos apenas teóricos, permitam o exercício de atividades metodológicas que ensinem a pesquisar, a desenvolver uma atitude profissional de investigação que seja incorporada, não só aos profissionais de saúde ou educação, mas aqueles que desejem estar sempre atualizados na busca do conhecimento e de práticas profissionais competentes.

O desenvolvimento científico e tecnológico, afeta a formação e o exercício profissional, contudo as mudanças nem sempre são positivas em relação à proliferação de cursos aligeirados de formação para atender o mercado ou a redução significativa da qualidade curricular com a minimização de carga horária comprometendo a formação no tocante aos conteúdos teórico-metodológicos e as praticas e o estágio, por outro lado, é importante não perder de vista como valorização do próprio profissional às exigências na formação dos balizadores da ética, da competência e da cidadania.

As diretrizes para atualização profissional, passam pela teoria, pela prática, pela busca do conhecimento. Nesta perspectiva, a pesquisa, enquanto procedimento acadêmico e profissional, vem se revelando um espaço, onde teoria e prática se encontram, resultando em conhecimentos produzidos, a partir das constatações dos dados avaliados e analisados, no percurso metodológico da pesquisa. Tais achados, sugerem novos rumos, novas alternativas para os problemas estudados, fazendo surgir então um profissional com conhecimento mais amplo, com uma formação de bases mais sólidas tanto do ponto de vista científico quanto com uma visão mais humanista de si e do outro.

A interrelação entre o ensino formativo, técnico e profissional, determina a prioridade dos cursos formativos, levando em conta a ética, o rigor cientifico e intelectual e o enfoque multi e interdisciplinar, especialmente na área da educação e saúde.

O compromisso com a competência da ação profissional, implica no conhecimento de questões sociais fundamentais como a eliminação da pobreza, a preservação do diálogo cultural, a consciência clara da relevância social de suas 
funções, onde quer que as desempenhem, aplicando os princípios da ética humana em todos os seus campos de ação.

O mundo psíquico dos seres humanos, está estreitamente ligado ao contexto que ele está inserido e a forma com que ele vive no decorrer da sua história.

Vigotsky (1996) já destacava em seus estudos, a importância de considerar, nos processos de aprendizagem, a origem e os contextos socioculturais dos alunos. Nesse sentido, discutimos aqui a importância do estudo das concepções e visões do conhecimento, cujo objetivo é capturar como se dão as interações num contexto social escolar e os significados, mediados por procedimentos psicopedagógicos, capazes de perceber e atuar como facilitadores das análise das diferenças humanas, enquanto configuração de uma intervenção psicopedogógica, política e sócio-histórica.

Os estudos, pesquisas e aplicações práticas e teórico metodológicas dos aportes psicopedagógicos oferecem um espaço de discussão sobre um leque de idéias até então estabelecidas, sobre aprendizagens, sobre a participação dos pais, sobre o envolvimento da equipe escolar e atendimento psicopedagógico, consolidando assim o trabalho do psicopedagogo.

Sabemos que durante muito tempo, qualquer pessoa diferente das consideradas normais, as pessoas com espectro autista, os considerados hiperativos e as pessoas com deficiência, aqueles com dificuldades de aprendizagem, tiveram o acesso à educação negado, sendo até muitas vezes consideradas incapazes de assimilar conhecimento. Contudo é sabido também que, nos últimos anos, aprofundaram-se as discussões sobre a inclusão, sobre os processos psicopedagógicos que permitem o acesso dessas pessoas à educação, através da elaboração de políticas de ações inclusivas.

A relevância da construção desse estudo, parte da necessidade de oferecer aos leitores interessados subsídios para analisar e refletir como o processo de inclusão das pessoas, como os problemas de aprendizagem, como se desenvolvem os indivíduos com diferentes síndromes, o que contribuirá de maneira significativa para aprofundamento teórico metodológico dos processos formativos dos psicopedagogos e dos profissionais que lidam com o humano, levando em consideração questões que caminham desde a necessidade de favorecimento às acessibilidades físicas e pedagógicas, às dificuldades pessoais, individuais e coletivas aqui estudadas.

As discussões, pautadas em diferentes abordagens metodológicas e aportes teóricos, retratam trechos de observação, identificação e atendimento para a permanência na escola e na sociedade inclusiva, de pessoas com deficiência, pessoas 
com dificuldades de aprendizagens e com outras ocorrências, que comprometem um desenvolvimento psicossocial e afetivo harmonioso.

É importante ter a justa medida de que é preciso efetivar medidas que valorizem as diferenças, garantindo oportunidades iguais de acesso ao conhecimento sócio-cultural construído, sem discriminações e segregações, bem como contribuir para a superação dos estigmas ao qual se encontram os alunos com deficiência, para que possam nela ingressar e participar da construção desse conhecimento.

Em relação às questões da criação de vínculos afetivos no universo escolar, a romantização da figura da tia, se confunde com o fazer por dever e o fazer por gostar, situações que tem desdobramentos na condição de um (a) profissional que desenvolve diferentes funções em diferentes etapas da vida escolar.

Acreditamos que o foco de atenção, são as experiências que já vêm sendo desevolvidas e as lacunas existentes na pespectiva de estabelecer diretrizes para as políticas de ações inclusivas, que precisam fazer parte de um processo de discussão e de intervenção na realidade, com base na compreensão de que não basta apenas atender aos dispositivos legais, mas fazer uma opção por uma política institucional que privilegie a inclusão social como uma ação fundante.

Nesse sentido, a permanência e a efetividade na qualidade do atendimento especializado inclusivo oferecido, o acesso a independência e autonomia através da parceria com a reabilitação, assim como a aprendizagem das várias formas de comunicação, faz com que esse livro coloque à disposição dos leitores uma produção intelectual, que num esforço de transposição didática, disponibilizam textos de leitura consistente e agradável.

$\mathrm{Na}$ observação, avaliação e intervenção das dificuldades de aprendizagem, o psicopedagogo realiza essas atividades especificas de sua função profissional, e faz parte de seu trabalho, auxiliar o professor a estimular o aluno a superar suas dificuldades. $\mathrm{O}$ estabelecimento de um diagnóstico deve ser muito mais relevante no sentido de descobrir as potencialidades e estabelecer um plano de trabalho que avaliar para elencar os problemas.

Além do encaminhamento do professor, das informações obtidas com a anamnese familiar o psicopedagogo deve considerar indícios das condições de desenvolvimento psicofísico da criança, seu contexto familiar social e cultural, o histórico escolar observando seus avanços e recuos no processo de aprendizagem e o comportamento da criança observada, construindo assim um diagnóstico 
circunstanciado e diferencial onde possa a partir dele estabelecer relações de ajuda profissional.

Os considerados hiperativos, ancorada nas idéias aqui discutidas baseadas nos estudos de Alan Ross (1999) e Genário Barbosa (2000), este texto tem por objetivo discutir problemas que vem se tornando muito constantes nas salas de aula: a dificuldade de atenção das crianças e os comportamentos hiperativos.

A atenção é fator fundamental para a aprendizagem. Esse entendimento ajuda no enfrentamento dos casos de insucesso escolar. O desenvolvimento cognitivo é responsável pela ampliação de nossas aprendizagens e para que isso aconteça é necessário deter-se sobre o objeto de estudo, refletir, analisar, realizar generalizações e fixar a aprendizagem.

Uma criança inquieta, com traços de agressividade a si e aos demais, que move-se constantemente, fala sem parar, tem movimentos circulares em torno da sala de aula, dos colegas, não consegue terminar suas tarefas, atrai para si a atenção dos colegas perturbando $\mathrm{o}$ andamento do trabalho pedagógico, tem problemas de atenção consequentemente de aprendizagem, por apresentar um comportamento hiperativo. A hiperatividade em geral tem causa neurológica, provoca desconforto para a criança para sua família e para a escola que não sabe o que fazer com ela.

Um dos aspectos mais significativos de uma escola competente, cidadã, é a formação e capacitação de seus(as) professores(as), de modo que, a esses(as) professores(as), sejam dadas condições práticas educacionais e pedagógicas de trabalhar com seus alunos com total participação na sala de aula.

Através da informação e reflexão a respeito das necessidades educacionais especiais, de atividades integradas orientadas por um/a professor/a que invista nos processos inclusivos, da reformulação de currículos, da articulação de conteúdos evitando a fragmentação teórica descontextualizada da prática, do conhecimento dos processos diferenciados de ensino-aprendizagem oferecidos ao/a professor/a certamente, os resultados psicopedagógicos dessa escola cidadã, esperados pelos pais e pela sociedade em geral, demonstrarão uma inclusão socioeducacional possível e sobretudo previne e minimiza as situações de risco que esses/as alunos/as estão expostos e que fazem com que representem por qualquer motivo, um grupo vítima de opressão ou discriminação

Diante das discussões postas até aqui, o que é uma situação de risco social? Como prevenir/proteger os/as alunos/as? Parece-nos que este cuidado psicopedagógico 
e formativo, precisa ser construído a partir da interiorização da aceitação, da ação colaborativa e da convivência com as diferenças, com a diversidade dos seres humanos. É a nossa capacidade de entender e reconhecer o outro, partilhando e acolhendo todas as pessoas sem exceção. Entendemos que inclusão antes de tudo é atitude, assim sendo, não pode ser imposta. A escola deve ser o reflexo da vida da sociedade e como tal, deve viver a experiência de conviver com as diferenças. um(a) professor(a), preocupado com a formação do humano, na perspectiva da inclusão, precisa ser capacitado e a escola cumpre seu papel, dando ao professor suporte pedagógico adequado através da construção de parcerias profissionais e institucionais, que poderão ser muito produtivas para seus(as) alunos(as) e para os (as) seus(as) professores(as).

A escola precisa começar a atender aquele(a) aluno(a) que não é o(a) ideal.

Os(as) alunos(as) e os(as) professores(as), não podem ser reféns de um currículo pedagógico mal organizado, incoerente, que não abre espaço para o talento das crianças e quem não acompanha o conteúdo, está fadado à exclusão e ao fracasso. A figura do psicopedagogo com um (a) profissional atuante que coordena as atividades educacionais otimizadoras, quando aliadas ao conhecimento proporcionado pela psicologia, pelas ciências da educação que trazem como consequiência imediata, o sucesso do desempenho acadêmico do(a) aluno(a), especialmente aquele (a) que apresenta alguma dificuldade de aprendizagem, facilitando sua inserção na comunidade que vive.

As dificuldades de aprendizagem, são questões vivenciadas diariamente nas escolas, despertando o interesse dos(as) educadores(as) e chamando a atenção para um grande número de crianças que freqüentam a escola e são traídas por suas dificuldades de adaptação, de metodologia ou de desenvolvimento desarmônico. Por muitos anos estas crianças foram mal diagnosticas, maltratadas ou ignoradas. Muitas são negras ou vindas das camadas sociais mais comprometidas economicamente, rotuladas como lentas, preguiçosas, até deficientes.

Seria ingênuo pensar, que uma escola seja capaz de mudar este estado de coisas, ter domínio de tantos conteúdos, de todo conhecimento produzido, mas a escola pode fazer muito, tendo um(a) professora qualificado(a) e comprometido(a), política e socialmente com a causa, tendo um currículo desafiador, que estimula e faz pensar as condições da comunidade, nas questões das relações de discriminação racial, étnica e na defesa dos direitos humanos,certamente estaríamos mudando a escola e conseqüentemente mudando a sociedade. 
Há uma necessidade de uma nova atitude educacional, junto aos cursos de formação de professores (as), a partir do paradigma da promoção da qualidade de vida e cidadania, com novas propostas pedagógicas para os contextos socioculturais e da análise do quadro educacional, onde certamente se constatará o grave problema instalado que cotidianamente expõe os alunos.

Observamos que, nos processos formativos de profissionais aqui em estudo, tanto na formação universitária, como em nível de especialização, não existe uma preocupação específica com a formação para lidar com as diferenças na sala de aula ou na escola.

Algumas disciplinas, de forma isolada, referem-se à formação do cidadão ou da cidadã, em particular, aquelas disciplinas que lidam com a educação inclusiva, contudo, não são momentos suficientes de preparação profissional que certamente terão alunos vitimas de discriminação e preconceito.

A aquisição de saberes, competências e habilidades para ensinar, nos cursos de formação, caminha muito mais para a instrumentalização do(a) docente em adquirir métodos e técnicas de ensino.

Os(as) professores(as) percebem na prática profissional, que a visão fragmentada que vivenciaram nos cursos de formação e as teorias que não foram desvendadas, os(as) levam à entender que a aprendizagem e a formação dos alunos representa uma complexa rede de relações. Estes são fatos que, em geral, só são percebidos quando os (as) docentes se formam e vão para o mercado de trabalho e então se sentem despreparados para "enfrentar" a sala de aula e seus problemas. Pensamos que é preciso reformar os currículos formativos e modificar a sala de aula, os meios que a escola dispõe para enfrentar a violência, a discriminação, o racismo e despertar a consciência dos alunos para as mazelas sociais, encontra na organização e construção do currículo, um espaço promissor. Rodrigues (2005) diz:

Entendemos que o currículo não é apenas um processo lógico de disciplinas articuladas e interdependentes, mas uma construção em diferentes pontos de vista, que devem ser considerados e analisados como produção do conhecimento e como expressão individual e coletiva, com a preocupação com a verdade e validade este conhecimento, a partir da historicidade e das dinâmicas sociais (RODRIGUES, 2005, p. 3)

Se não houver no espaço escolar onde este currículo é vivenciado, uma concepção de educação que incorpore e integre o ato pedagógico como causa e 
consequiências inseparáveis, o currículo diante disto, fica como que solto, sem sentido e a escola perde o seu papel como tarefa política e social, voltada para uma educação mais democrática e efetiva na comunidade, promovendo assim a construção da cidadania e cidadania

\section{Algumas considerações finais}

É importante lembrar a ação conjunta das ciências humanas no favorecimento do processo de construção do conhecimento do aluno que desenvolve sua capacidade de argumentação.

Essas competências do agir pedagógico implicam em novas formas de ensino, a reorganização do espaço escolar com a presença de outros profissionais advindo de outros campos do saber como: Neurologia, Fonoaudiologia, Psicologia, entre outros parceiros, que trazem novos significados pedagógicos na luta contra exclusão social construindo entre eles, a disponibilidade para um diálogo de múltiplas faces em diferentes espaços sociais.

Esperamos com estas colocações, ter contribuído para aprofundar as discussões sobre a importância das práticas psicopedagógicas e educativas na ótica da diversidade, a partir da formação pessoal e profissional, embasada na perspectiva da educação como formação do humano.

Nesse sentido, o trabalho psicopedagógico se constitui numa teia de relações ampliando ou reduzindo focos de analises das práticas sociais, diluídos em teorias, currículos, condutas numa aprendizagem acadêmica seletiva. A convivência de um currículo comum, a diversidade pedagógica, a atenuação dos efeitos da desigualdade, pluralidade de formas de viver, pensar e agir, expressão genuína da comunidade humana, provoca e facilita a reconstrução do conhecimento.

Cabe ao Psicopedagogo, avaliar psicopedagogicamente, diagnosticar as interpretações da realidade oferecendo elementos para construção da criticidade e pautas de conduta, provocando a organização racional das informações com experiências e intervenções psicopedagógicas nos processos de aprendizagem.

Promover e desenvolver a pesquisa nas ações tanto formativas dos profissionais da saúde e da educação como em suas práticas no exercício profissional, são passos necessários na trajetória formativa e profissional, dada sua relevância para o desenvolvimento de estudos objetivos e oportunos, que garantam um processo 
contínuo em busca do acesso aos bens culturais, a saúde e a educação como direito assegurado constitucionalmente, para todos.

A pesquisa como instrumento de busca e produção do conhecimento, favorece o reconhecimento do ensino e aprendizagem em diferentes contextos. A divulgação de resultados de pesquisa mundiais, vem criando oportunidades de diminuição da distância entre países considerados mais desenvolvidos e países considerados emergentes ou menos desenvolvidos, no âmbito da produção do conhecimento.

As ações cooperativas, os grupos integrados de pesquisadores, são uma realidade. Integrados e interligados, através das redes, dos sites da Internet, conversando por e-mail, navegando nos espaços pelo mundo da tecnologia, via virtual ou não, os pesquisadores do mundo inteiro hoje dialogam, desenvolvem ações colaborativas e os resultados positivos das pesquisas, são socializados, continuados, havendo uma cooperação internacional visando a melhoria da qualidade de vida dos povos.

Refazer passos de aprendizagem, construir atalhos psicopedagógicos aponta para a reconstrução critica do pensamento e da ação transformadora das práticas psicopedagógicas que oportunizam o resgate da cidadania, põe as “análises" nos seus devidos lugares quando destaca as causas dos comprometimentos e anuncia como minimizá-los, distanciando da idéia de que, se a criança não aprende, é por culpa, por falta de capacidade individual.

\section{REFERÊNCIAS}

ASINELLI-LUZ, A. Educação e cidadania: a formação continuada de professores e a perspectiva da não-exclusão na escola In: ASSIS, M. C. de; ASSIS, O. Z. Mantovani (Orgs.). Educação e cidadania. Anais... XXII Encontro Nacional de Professores do PROEPRE. Campinas: FE, 2005.

BRASIL. Secretaria de Estado de Assistência Social. Projeto Centro Nacional de Formação Comunitária. Brasília, [1998].

BASSEDAS, E. et al. Intervenção educativa e diagnóstico psicopedagógico. Porto Alegre: Artmed. 1996

BECKER F. Educação e construção do conhecimento. Porto Alegre: Artmed.2001.

BRASIL. Estatuto da Criança e do Adolescente, Lei Federal n. 8.069/90, de 13 de julho de 1990, dispõe sobre a proteção integral à criança e ao adolescente. Brasília: Ministério da Justiça, 1995. 
BRASIL. Constituição da República Federativa do Brasil. Promulgada em 5 out. 1988. São Paulo: Atlas, 1999.

CADERNOS CEDES, n. 35. Implicações pedagógicas do modelo histórico cultural. 2 ed., jul. 2000.

CARVALHO J. M.; MACHADO M. C. G. Imaginário social e processos de institucionalização da produção acadêmica científica sobre a questão do professor. In: Revista Estudos. Mestrado em Educação da UCDB. MT, nº 14, 2002.

CIASCA, S. M.; ROSSINI, S. D. R. Distúrbio de aprendizagem: mudanças ou não? Correlação de uma década de atendimento. Temas sobre desenvolvimento, 8(48): 11$16,2000$.

COSTA, A. C. G. da. O Estatuto da criança e do adolescente e a política de atenção à infância e à juventude. In: Ciclo de Seminários: discutindo a assistência social no Brasil, 1995.

FRANZOI, N. L. Entre a formação e o trabalho trajetória de identidades profissionais. Porto Alegre: Ed UFRGS, 2006.

FREIRE, P. Pedagogia do oprimido. RJ: Paz e Terra, 1997.

FREIRE, P. Pedagogia da autonomia. RJ: Paz e Terra, 2002.

FONSECA, V. Introdução às dificuldades de aprendizagem. 2 ed. Porto Alegre: Artes Médicas, 1995.

JESUS N. Manual de dificuldades de aprendizagem. Porto Alegre: Artmed. 1998.

GRÉGOIRE. J. Avaliando as aprendizagens: os aportes da psicologia cognitiva. Porto Alegre: Artmed. 2000

GIMENO SACRISTAN, J.; PÉREZ GÓMEZ, A. I. Compreender e transformar o ensino. Porto Alegre: Artmed 2009

IPEA - Instituto de Pesquisa Econômica Aplicada. PNAD, 2007. Disponível em: <http://www.ipea.gov.br/sites/000/2/comunicado_presidencia/ 08_10_07_Pnad_PrimeirasAnalises_N11demografia.pdf >. Acesso em: 15 maio 2008.

MACHADO. N. Epistemologia e Didática. SP: Cortez 1999.

MINAYO, M. C. de S. O desafio do conhecimento. São Paulo: Hucitec, 1993.

NEGRINI. A. Aprendizagem e desenvolvimento infantil. RS: Prodil. 1996

NOGUEROL, A. Aprender na escola. Porto Alegre: Artmed, 1999.

OLIVEIRA. V. F. (Org) Imagens de professor. Ijuí: Ed. Inijui.2000. 
PARANÁ. Conselho Estadual de Defesa da Criança e do Adolescente. Política de atendimento dos direitos da criança e do adolescente no estado do Paraná. 3 ed. Curitiba: CEDCA, 20

PADILHA, A. M. L. Práticas pedagógicas em educação especial. Campinas, 2001.

PLACCO, V. (Org). Psicologia e educação: revendo contribuições. SP: Educ, 2000.

PRADA. L. Formação participativa de docentes em serviço. Taubaté: Cabral Ed. Universitária, 1998.

POZO, J. Aprendizagens e mestres. Porto Alegre: Artmed. 2002.

RICCIO, C. Neurological basis of attention déficit hyperactivy disorder. The Concil for exceptional Childdren, n. 2, 1999.

RODRIGUES, J. M. C. et al. O Insucesso escolar. João Pessoa: Revista Conceitos, Aduf.

RODRIGUES, J. M. C. et al. Construindo trilhas refazendo caminhos. João Pessoa: Ed Ideias, 2013.

RODRIGUES, J. M. C. Afetos e desafetos na educação infantil. Artigo. Creche. UFPB, 2001.

RODRIGUES. J. M. C. Um estudo sobre a dislexia. UFPB/CE/JP. 2001.

RODRIGUES, J. M. C; GAUDENCIO, R. (Org). Formação docente: coletando textos, discutindo idéias. JP: Ed. Universitária, 2004.

RODRIGUES, J. Construindo a profissionalização docente. JP: Ed Universitária, 2003.

RODRIGUES. J. M. C. O autista e sua educação.JP: Ed Universitária, 2005.

RODRIGUES. J. M. C. Autismo: um estudo psicopedagógico. RJ: Wak, 2010. RODRIGUES. J. M. C.; FERNANDES, W. L. V. (Org). Trabalhando as diferenças com os (des)iguais. JP: Ed Universitária, 2004.

ROSS, A. Aspectos psicológicos dos distúrbios de aprendizagem da leitura e da escrita. Mac. Graw Hill, 1997.

SANTOS, E. A. dos. Criança e adolescente sujeitos de Direito. Revista IBCT. Disponível em: <http://revista.ibict.br/inclusao/index.php/inclusao/article/view/56/78>. Acesso em: 9 jul. 2008.

SOARES, M. Linguagem e escola uma perspectiva social. SP: Ed. Ática, 2000.

SCHON. D. Educando o profissional reflexivo. Porto Alegre: ArtMed, 2002. 
SCRIPTORI, C. C. Cidadania e escola: alguns pontos de reflexão sobre os caminhos de uma educação para a cidadania. In: ASSIS, M. C. de.; ASSIS, O. Y. Z. M. (Orgs).

Educação e cidadania. XXII Encontro Nacional de Professores do PROEPRE.

Campinas: FE, 2005.

VERONESE, J. R. P.; RODRIGUES, W. M. A figura da criança e do adolescente no contexto social: de vítimas a autores de ato infracional. Brasília: ABMP, 2001.

\section{Como referenciar este artigo}

RODRIGUES, Janine Marta Coelho.; ARAGÃO, Wilson Honorato.; RODRIGUES, Silvestre Coelho. Políticas públicas de educação no Brasil: fracasso escolar, culpabilização dos alunos e inocentização da escola. Revista on line de Política e Gestão Educacional, Araraquara, v. 21, n. esp. 02, p. 000-000, nov. 2017. Disponível em: <http://dx.doi.org/10.22633/rpge.v21.n.esp2.2017.10372>. ISSN: 1519-9029.

Submetido em: 05/09/2017

Aprovado em: 10/10/2017 